\title{
PENGARUH KOMUNIKASI \\ DAN MOTIVASI KERJA KEPEMIMPINAN KEPALA SEKOLAH TERHADAP KINERJA TENAGA PENDIDIK, DI MA MATHOLI'UL ANWAR KABUPATEN LAMONGAN
}

\author{
Misbahus Surur, Muhammad Siroj Hakim \\ UIN Sunan Ampel, Surabaya - Indonesia | Misbahussurur687@gmail.com
}

\begin{abstract}
Abstrak: This study aims to determine the effect of school principal, communication, and work motivation on MA Matholi'ul Anwar Sungelebak Karanggenang teachers in Lamongan Regency. This research is a type of qualitative research using a case study approach to understand the phenomena about what is experienced by research subjects. analysis using interpretative descriptive research, the researcher conducts research based on literature literature and observations in the field, namely through observation and interviews with research objects, as the main method. The results in this study indicate that leadership, communication, and work motivation affect the performance of MA Matholi'ul Anwar Sungelebak Karanggenang teachers in Lamongan Regency. partially the most influential is leadership on the performance of teaching staff communication and work motivation.
\end{abstract}

Keywords: Communication, Work Motivation and Leadership.

\section{Pemdahuluan}

Banyak orang berbicara tentang merosotnya mutu pendidikan, di lain pihak banyak pula yang mengemukakan perlu dan pentingnya pembaharuan sistem pendidikan dan pengajaran, akan tetapi sedikit sekali yang berbicara tentang konsep- konsep pemecahan masalah perbaikan sistem pendidikan dan pengajaran.

Seiring berkembangnya zaman modern, khususnya keberadaan telepon genggam, yang mana komunikasi verbal sukar ditemukan, sehingga telepon genggam dirasa cukup mewakili dalam berintraksi sosial maupun memberikan informasi. Hal ini bisa saja berdampak buruk terhadap tersampaikannya atau tidak informasi 
yang di berikan, bahkan cenderung menimbulkan kesalahfahaman bagi penerima informasi.

Dalam fenomena ini guru berada dalam komponen yang sangat penting, sehingga guru merupakan sumberdaya manusia yang harus dibina dan dikembangkan terus-menerus. Pembentukan profesi guru dilaksanakan melalui program pendidikan pra-jabatan maupun program jabatan. Tidak semua guru yang di didik di lembaga pendidikan terlatih dengan baik dan kualified. Potensi sumberdaya guru itu perlu terus bertumbuh dan berkembang agar dapat melakukan fungsinya secara potensial. Selain itu pengaruh perubahan yang serba cepat mendorong guru-guru untuk terusmenerus belajar menyesuaikan diri dengan perkembangan ilmu pengetahuan dan tekhnologi serta mobilitas masyarakat.

Undang-Undang Nomor 20 Tahun 2003 tentang Sistem Pendidikan Nasional, yang memiliki visi terwujudnya sistem pendidikan sebagai pranata sosial yang kuat dan berwibawa untuk memberdayakan semua warga Negara Indonesia berkembang menjadi manusia yang berkualitas sehingga mampu dan proaktif menjawab tantangan zaman yang selalu berubah.

Menurut Ngalim Purwanto untuk menjawab permasalahan itu dapat dilakukan usaha-usaha sebagai berikut: 1 . Membangkitkan dan merangsang semangat guru-guru dan pegawai sekolah dalam menjalankan tugasnya dengan sebaik-baiknya. 2. Berusaha mengadakan dan melengkapi perlengkapan termasuk macammacam media instruksional yang diperlukan bagi kelancaran jalannya proses belajar mengajar. Disinilah urgensi peran kepemimpinan kepala sekolah di pertimbangkan, agar lembaga pendidikan berjalan sesuai dengan apa yang di harapkan.

Kepala sekolah/madrasah dapat di definisikan sebagai seorang tenaga fungsional guru yang di beri tugas untuk memimpin. Adapun kepemimpinan adalah kemampuan untuk menciptakan perubahan yang efektif dalam perilaku kelompok untuk pencapaian tujuan-tujuan yang di tetapkan.(Rohiat,2008:14) Kepemimpinan menurut Terry dalam Davis (1985) "Leadership is the relationship in which one person, or the leader, influences others to work togethet willingly on related tasks to attain that which the leader desires", 
kepemimpinan adalah proses mendorong dan membantu orang lain untuk bekerja dengan antusias guna mencapai tujuan. pada sekolah yang mana di selenggarakan proses belajar mengajar atau tempat di mana ada interaksi antara guru yang memberi pelajaran dan murid yang menerima pelajaran semuanya pasti ada yang memimpin sebuah organisasi agar berjalan baik. Siapapun yang akan di angkat menjadi kepala sekolah harus di tentukan melalui prosedur serta persyaratan-persyaratan tertentu seperti latar belakang pendidikan, pengalaman, usia dan integritasnya.

Sebagai manajer kepala sekolah harus mampu bekerja sama dengan orang lain dalam organisasi sekolah. Sebagai pemimpin pendidikan kepala sekolah harus mampu mengkoordinasi dan menggerakan potensi manusia untuk mewujudkan tujuan pendidikan, sebagai pimpinan kepala sekolah harus mampu membantu guru dalam meningkatkan kapasitasnya untuk pembelajaran murid secara optimal.

Kepala sekolah/madrasah sebagai pemimpin tertinggi di suatu lembaga memiliki peranan sangat penting dan vital dalam mengelola lembaga pendidikan, karena maju mundurnya lembaga berada di tanggung jawabnya. Seorang pemimpin harus bisa berkomunikasi yang baik, memberikan motivasi dan memberikan pengaruh terhadap anggotanya secara bersama-sama bekerja untuk mewjudkan visi yang di tetapkan pada sekolah yang di kelola.

Agar organisasi lembaga pendidikan dapat terko'ordinasi dengan baik, di butuhkan pula komunikasi yang baik antar jajaran. Istilah "komunikasi" berasal dari bahasa Latin "communicatio" berasal dari kata "communis" yang dalam bahasa Inggrisnya "communication" yang berarti "sama" atau "sama maknanya" atau bisa juga diartikan dengan "pengertian yang sama".

Komunikasi merupakan penyampaian pesan dari seseorang kepada orang lain melalui lisan, tulisan atau isyarat sehingga orang lain memahami, mengerti dan jelas dengan pesannya itu. Para ahli memberikan definisi komunikasi cukup beragam, seperti James A.F. Stoner "komunikasi adalah proses dimana seseorang berusaha memberikan pengertian dengan cara pemindahan pesan". John R. Schemerhorn menyatakan "proses antar pribadi dalam mengirim 
dan menerima simbol-simbol yang berarti bagi kepentingan mereka".

Secara sederhana pengertian komunikasi adalah proses penyampaian pikiran, perasaan dari seseorang kepada orang lain. Pendapat lain menyatakan, komunikasi sebagai pengoperan ide dan gagasan untuk menyatukan kekuatan sehingga terjadi interaksi antara orang-orang yang berkomunikasi menuju pencapaian tujuan bersama (kesamaan makna).

Pengakuan sebuah jasa yang sudah di lakukan oleh seseorang khususnya dalam lembaga pendidikan sangatlah penting. Menurut Kanfer dalam bukunya Ismail Solihin (Ismail Solihin, 2009, p. 152) motivasi merupakan kekuatan psikologis yang akan menentukan arah dari perilaku seseorang, tingkat upaya dari seseorang, dan tingkat ketegaran pada saat orang itu dihadapkan pada berbagai rintangan.

Hadari Nawawi dalam bukunya Badrudin (Badrudin, 2013, p. 192) mengemukakan fungsi motivasi bagi manusia yaitu sebagai energi atau penggerak bagi manusia, pengatur memilih alternatif diantara dua atau lebih kegiatan yang bertentangan, dan pengatur arah atau tujuan dalam melakukan aktivitas.

Menurut Ngalim Purwanto bahwa tujuan motivasi adalah untuk menggerakkan atau menggugah seseorang agar timbul keinginan dan kemauannya untuk melakukan sesuatu sehingga dapat memperoleh hasil atau mencapai tujuan tertentu. Bagi seorang manajer dalam lembaga pendidikan tujuan motivasi ialah untuk menggerakkan pegawai atau bawahan dalam usaha meningkatkan prestasinya sehingga tercapai tujuan organisasi yang dipimpinnya. Bagi seorang guru, tujuan motivasi adalah untuk mengerakan atau memacu para siswanya agar timbul keinginan dan kemauannya untuk meningkatkan prestasi belajarnya sehingga tercapai tujuan pendidikan sesuai dengan yang diharapkan dan ditetapkan didalam kurikulum sekolah. (Ngalim Purwanto, 2002, p. 73)

Berdasarkan tinjauan teori penelitian terdahulu dan tinjauan teori di atas maka dapat dirumuskan hipotesis sebagai berikut, yaitu : H1:Terdapat pengaruh, komunikasi, dan motivasi kerja, 
kepemimpinan kepala madrasah terhadap kinerja tenaga pendidik H2:Terdapat pengaruh signifikan antara variabel kepemimpinan terhadap kinerja tenaga pendidik.H3:Terdapat pengaruh signifikan antara variabel komunikasi terhadap variabel kinerja tenaga pendidik.H4:Terdapat pengaruh signifikan antara variabel motivasi terhadap kinerja tenaga pendidik.

\section{Profil Madrasah}

Sejarah Berdirinya MA. Matholi'ul Anwar Simo Sungelebak Pesantren "Matholi'ul Anwar" didirikan pada 18 Januari 1914 oleh K.H. Abdul Wahab. Pada masa tersebut belum berwujud pesantren sebagaimana pengertian sekarang yaitu ada Kyai, tempat ibadah, tempat santri dan sarana belajar, namun masih berupa pengajianpengajian rutin dimana rumah Kiai sebagai tempatnya. K.H. Abdul Wahab kembali ke Rahmatullah pada tanggal 12 maret 1925.

Setelah Founding father tersebut meninggal dunia, maka pengajian tersebut dilanjutkan oleh putra-putra menantu beliau yaitu K.H. Abdullah, K.H. Rusman dan K.H. Dja'far. Kepengasuhan beliau bertiga tersebut berjalan hingga tahun 1935.

Adapun semenjak 17 Juli 1935 kepengasuhan pesantren digantikan oleh K.H. Soefyan Abdul Wahab, yang ketika itu beliau baru berumur 18 tahun dan sedang giat- giatnya mengenyam ilmu di berbagai pesantren di sekitar kabupaten Lamongan, termasuk di pesantren Langitan. Dalam usia yang masih sangat belia tersebut, beliau mengasuh pesantren sekaligus juga mondar-mandir menimba ilmu kepada beberapa Kyai dengan pengajian sorogan. Hal ini dapat dipahami bahwa tanggung jawab beliau secara pribadi dan sosial sangat besar dan seimbang.

Usia 18 tahun untuk memimpin jama'ah pada era dewasa ini nampaknya terlalu muda. Namun kala itu, kharisma dan kepribadian beliau sebagai putra Kyai memang layak untuk menyandang derajad tersebut, demikian pula tanggung jawab yang sedemikian besar dalam memimpin ummat harus diiringi dengan kemampuan yang baik dalam penguasaan keilmuan maupun kepemimpinan.

Untuk itulah saudara-saudara ipar beliau yang lebih tua dan alim memberikan kepercayaan dan tanggung jawab penerusan dan 
kepengasuhan pesantren kepada beliau. Sebagai perwujudan tanggung jawab tersebut, beliau menerima amanat dengan niat semata-mata pengabdian dan penghambaan kepada Allah, di samping itu tak henti- hentinya beliau terus meningkatkan belajarnya.

Semangat mencari ilmu seperti yang dipraktekkan Kyai Soefyan sudah sepatutnya ditiru dan diteladani oleh para santri, pelajar, dan ummat, misalnya kebiasaan Kyai Soefyan yang selalu istiqomah muthola'ah kitab-kitab hingga larut malam. Kebiasaan ini masih beliau lakukan hingga sehari menjelang wafat beliau. Beliau juga selalu terbuka sekaligus selektif terhadap arus informasi. Sikap tawazun, tawassuth, dan i'tidal menjadi bagian dari kepribadian beliau. Beliau juga mempunyai kebiasaan membaca. buku-buku umum atau aktual berikut berlangganan majalah dan koran yang kala itu bagi lingkungan pesantren yang masih dirasa asing. Tidak mengherankan, dengan kebiasaan demikian menjadikan wawasan beliau sangat maju dan tidak tertinggal oleh arus informasi yang relevan dengan pengembangan keislaman, kemasyarakatan dan kondisi sosial-politik.

Kepribadian dan akhlaq beliau juga patut dijadikan sebagi teladan bagi kita. Beliau selalu menghargai pendapat orang lain, mendengarkan dua kali lebih banyak dari pada berbicara, mengasihi kaum lemah, nada suaranya teduh dan menyejukkan hati bagi orang lain, ketika berceramah tidak menjadikan orang lain tersinggung, mengasihi orang miskin dan menghormati orang kaya. Hal ini nampak dari kebiasaan beliau jika di undang oleh seseorang dalam hari dan jam yang hampir bersamaan, yang satu miskin dan yang lain kaya, maka beliau datang dulu kepada orang miskin tersebut, baru kemudian kepada orang kaya.

Dalam bidang sosial kemasyarakatan dan kepemerintahan, pribadi beliau pantas teladani ummat Islam. Misalnya dalam kesibukan mengajar di madrasah, mengaji di pesantren dan ceramah di tengah-tengah masyarakat, beliau masih menyempatkan menjadi Ketua Tanfidliyah NU Karanggeneng, hingga beliau pernah mewakili Partai NU duduk sebagai anggota DPRD Tingkat II Lamongan. Demikian juga dalam hal pemerintahan, beliau juga 
pernah menjadi anggota tim P-7 Jawa Timur. Demikian ini didorong oleh motivasi beliau untuk mewujudkan fungsi dan posisi pesantren secara maksimal. Pada saat yang sama, berbagai kesibukan dalam urusan masyarakat dan pemerintah tersebut tidak menjadikan pengurangan perhatian beliau pada pengembangan pesantren dan lembaga-lembaga yang ada di dalamnya.

Semenjak kepengasuhan pesantren dipegang oleh Kyai Soefyan, maka diadakan pengembangan-pengembangan pesantren yang sangat bermakna dan berdampak sampai dewasa ini. Pengembangan dimaksud bukan hanya pengajian level kampung seperti pada masa kepengasuhan sebelumnya, namun pengembangan yang menjadikan suatu bibit pesantren menjadi pesantren yang sesungguhnya. Pada masa beliau inilah telah lengkap unsur kyai, langgar (musholla) dan asrama (pondokan), hal ini terjadi pada 1 Januari 1949. Perkembangan ini tentu tidak terlepas dari ilmu, kharisma dan kepribadian beliau sebagai sosok pengasuh.

Dengan didirikannya pesantren, respon masyarakat sangat positif. Pertumbuhan yang postif itu dapat dilihat, kalau pada awal mula santrinya hanya 3 orang, maka dua tahun berikutnya sudah menjadi 60 orang. Dengan banyaknya murid atau santri tersebut, maka beliau mendirikan sekolah formal, yaitu tepatnya pada tahun 1951. Sekolah yang dibuka tersebut adalah Madrasah Ibtida'iyah. Pendirian madrasah tersebut tidak terlepas dari dorongan dan saran para Kyai dan pejabat kabupaten Lamongan, misalnya dari K.H. Mustaqim dan Bapak Susminto, seorang Hakim di Lamongan kala itu.

Pengembangan demi pengembangan semakin pesat, dan mendapat respon positif dari masyarakat, sehingga santrinya semakin pesat. Untuk itu perlu disediakan sarana belajar yang memadai pula, bukan hanya pendidikan tingkat dasar (MI), namun juga pendidikan formal yang lebih tinggi yaitu Madrasah Tsanawiyah (dahulu MMP) yang didirikan tahun 1959 dan Madrasah Aliyah (dahulu MMA) yang didirikan sepuluh tahun kemudian yakni pada tahun 1969. 
Dari sini kita dapat mengambil pelajaran, bahwa semangat beliau dalam mencerdas- akhlaqkan generasi muda sangat tinggi atau dapat dilihat dari cara beliau berfikir yang menampakkan progresifitas ide jauh ke depan. Sebagai salah satu buktinya, semenjak tahun 1979 beliau sudah mempunyai ide untuk mendirikan lembaga pendidikan lanjutan pertama dan atas yang bersifat umum (SMP dan SMA), perguruan tinggi, rumah sakit, dan penerbitan. Biar pun pendidikan lembaga umum tersebut belum didirikan hingga beliau kembali ke Rahmatulloh, namun tebaran ide itu masih senantiasa beredar dalam komunitas penerusnya untuk diambil sebagai program pengembangan pesantren pada masa sekarang dan ke depan.

Hingga 20 Januari 1983 saat K.H. Soefyan Abdul Wahab pulang ke Rahmatullah, jumlah murid dan santri Pondok Pesantren Matholi'ul Anwar dengan berbagai unit yang ada yaitu Madrasah Banin Banat, Madrasah Tsanawiyah dan Madrasah Aliyah sudah cukup lumayan yaitu lebih 1250 orang. Namun, tidak berarti bahwa dengan wafatnya beliau pengembangan pesantren menjadi stagnan, justru semangat dan cita-cita beliau senantiasa dilanjutkan dengan memegang mata rantai penghargaan terhadap tradisi yang ada dengan terus berusaha mengaktualisasikan, inovatif dan akomodatif terhadap perkembangan baru di sekelilingnya.

Setelah meninggalnya beliau, maka kepemimpinan dilanjutkan oleh K.H. Mahsuli Effendi (sekaligus beliau melanjutkan tugas sebagai kepala sekolah di MA Matholi'ul Anwar) dan putra-putra menantu beliau antara lain Drs. K.H. Masykuri Shodiq, S.H., Drs. K.H. Moh.Taufiq dan Drs. K.H. Saifuddin Zuhri, MA. Selain itu, tentu saja peran dari Ibu Nyai Hj. Masfiyah Soefyan sebagai orang tua yang sangat bijaksana dan pengayom yang baik, serta putriputri beliau yakni Ny. Hj. Shofiyah Mahsuli, Ny. Dra. Hj. Siti Zaenab Anwar, Ny. Dra. Hj. Siti Djamilah Masykuri, Ny. Hj. Dra. Siti Aisyah Taufiq, dan Ny. Dra. Hj. Khotimah Suryani Saifuddin juga cukup mewarnai dinamika kepemimpinan yang ada. Hampir tidak ada keputusan penting yang di ambil lembaga ini tanpa melalui ijin, restu dan istikharah Ibu Nyai Hj. Masfiyah Soefyan. 
Formasi kepemimpinan tersebut berkurang sejak tahun 2001, yakni ketika dua putra menantu beliau Kyai Masykuri dan Kyai Saifuddin dipanggil ke Haribaan Yang Maha Kuasa pada tanggal 26 Juni 2001, atau tiga hari sebelum pelaksanaan Haul Kyai Soefyan yang ke XVIII.

K.H. Mahsuli Effendi dalam kepemimpinannya sebagai Kepala MA Matholi'ul Anwar memberikan kemajuan yang signifikan baik dalam perkembangan siswa maupun sarana prasarana. Tiap tahun jumlah siswa baru selalu bertambah, tidak hanya dari daerah sekitar dan Lamongan saja, tetapi juga dari luar daerah bahkan dari luar pulau. Ini menunjukkan bahwa madrasah sudah menjadi tujuan utama masyarakat dalam membentuk akhlak dan kelilmuan peserta didik.

KH. Mahsuli Effendi mengabdi di MA Matholi'ul Anwar kurang lebih dari 28 tahun, karena pada hari Kamis kliwon, tanggal 8 Desember 2011 beliau dipanggil Allah swt, dan untuk melanjutkan perjuangan beliau di MA Matholi'ul Anwar, mulai tahun 2012 - 2015 kepemimpinan di MA Matholi'ul Anwar diserahkan kepada putra menantu beliau yaitu Drs. Khotib, M.Ag. Dan mulai tahun 2015 - sekarang tongkat estafet kepemimpinan di emban oleh Drs. H. Ali Musta'in, M.Ag.

Seiring dengan perjalanan waktu MA Matholi'ul Anwar telah tumbuh menjadi madrasah yang berkembang dan maju baik siswa maupun sarana yang ada, dan sampai sekarang MA Matholi'ul Anwar sudah meluluskan +8700 siswa/siswi.

\section{Metodologi}

Penelitian ini adalah jenis penelitian kualitatif dengan menggunakan pendekatan studi kasus. Penelitian kualitatif adalah penelitian yang dimaksudkan untuk memahami fenomena tentang apa yang dialami oleh subjek penelitian misalnya perilaku, persepsi, motivasi, tindakan, dan lain-lain secara holistik, dan dengan cara deskripsi dalam bentuk kata-kata dan bahasa, pada suatu konteks khusus yang alamiah dan dengan memanfaatkan berbagai metode alamiah. Penelitian dilaksanakan dalam suasana wajar dan alamiah dalam berbagai konsep dan teori yang dikembangkan berdasarkan kondisi atau kenyataan dilapangan kemudian dilaporkan dalam 
catatan-catatan berdasarkan perspektif dan sudut pandang kejadian/peristiwa tersebut. Dimaksudkan untuk mengungkapkan implementasi secara deskriptif mengenai "Pengaruh Komunikasi, dan Motivasi Kerja Kepemimpinan Kepala Sekolah Terhadap Kinerja Tenaga Pendidik, di MA Matholi'ul Anwar Kabupaten Lamongan".

Berdasarkan analisis dengan menggunakan jenis penelitian deskriptif interpretatif maka peneliti melakukan penelitian berdasarkan literatur kepustakaan dan observasi di lapangan, yaitu melalui observasi dan wawancara terhadap objek penelitian, sebagai metode yang utama. Hasil observasi dan wawancara dengan metode deskriptif interpretatif itu menggunakan analisis isi melalui data yang ada, kemudian menginterpretsi dan dideskripsikan secara lengkap.

Metode penelitian kualitatif itu dilakukan secara intensif, peneliti ikut berpartisipasi dilapangan mencatat secara hati-hati apa yang terjadi, melakukan analisis reflektif terhadap lembaran dokumen yang ditemukan dilapangan dan membuat laporan penelitian secara mendetail.

Waktu dan Tempat Penelitian. Penelitian di laksanakan pada Tanggal 20 Agustus-29 September 2019. Adapun tempat penelitian ini adalah di MA Matholi'ul Anwar Kabupaten Lamongan.

Tekhnik Pengumpulan Data. dalam penelitian kualitatif menurut Lofland. Lofland mengatakan sumber data dalam penelitian ini adalah dengan kata-kata dan tindakan, selebihnya adalah data tambahan seperti dokumen atau bahan lain. Data yang akan digunakan dalam penelitian ini antara lain: Kata-kata dan tindakan, berupa hasil wawancara dan pengamatan tentang Pengaruh Komunikasi, dan Motivasi Kerja Kepemimpinan Kepala Sekolah Terhadap Kinerja Tenaga Pendidik, untuk mengetahui pengaruh intensitas kinerja kependidikan pada MA Matholi'ul Anwar.

Data tertulis, profil, visi misi instansi atau lembaga pendidikan berupa dokumen- dokumen atau kegiatan yang menjadi faktor pendukung dalam pelasanaan penelitian di MA Matholi'ul Anwar. 
Pengumpulan data dari suatu proses pengadaan data primer untuk keperluan penelitian. Pengumpulan data merupakan langkah yang amat penting dalam metode ilmiah, karena pada umumnya data yang dikumpulkan digunakan. Sumber data dalam penelitian ini adalah Kepala Sekolah, Waka Kurikulum, Waka Kesiswaan dan beberapa guru yang mengajar di MA Matholi'ul Anwar.

Sedangkan teknik atau metode pengumpulan data dalam penelitian ini ada 3 jenis metode, adalah metode observasi, wawancara, dan kajian pustaka.

\section{Hasil dan Pembahasan}

Peningkatan ini dapat di lihat dari jumlah peserta didik dari tahun ke tahun yang semakin meningkat. Tidak hanya peningkatan jumlah peserta didiknya saja, akan tetapi pada lulusannya yang juga banyak di terima lembaga perguruan tinggi negei favorit. Hal ini di peroleh dari kerjasama yang baik antara pimpinan dan bawahan, tutur kepala sekolah.

Dalam pemberian apresiasi terhadap siswa yang berprestasipun, baik yang di adakan oleh tingkat Provensi maupun tingkat Nasional. Lembaga kami memberikan beasiswa berupa gratis spp semester maupun penuh. Agar para siswa terus terpacu untuk selalu mengembangkan potensinya, baik akademik maupun nonakademik. Bagi siswa yang dirasa kurang berprestasi, lembaga kami mewadahi pengembangan khusus, seperti adanya program ekstrakurikuler agar terwujud pemerataan sistem pembelajaran bagi siswa, tutur kesiswaan.

MA Matholi'ul Anwar telah di percaya oleh masyarakat luas di sekitar Kab Lamongan maka untuk mempertahankan kepercayaan masyarakat maka perlu adanya usaha untuk meningkatkan kualitas tenaga pendidik(guru) pada MA Matholi'ul Anwar Lamongan yang ternyata masih sangat perlu di tingkatkan keprofesionalismenya, di antara guru guru pengajarnya masih banyak guru yang mengajar absen dengan alasan tertentu, sedangkan yang harus di hadapi sekitar 43 rombel yang harus di layani.

Peran Kepemimpinan Kepala Sekolah MA Matholi'ul Anwar Lamongan dalam meningkatkan keprofesionalisme tenaga pendidik menjalin komunikasi yang baik dan memberikan motivasi kepada 
setiap tenaga pendidik, tidak hanya siswa merasakan motivasi dan dukungan, namun tenaga pendidik juga harus di motivasi dan di apresiasi dalam rangka mencapai tujuan yang telah di canangkan, tutur kepala sekolah.

Peranan guru di era globalisasi sangat penting, sebab hanya melalui bimbingan guru yang profesional, kami mengadakan MGMP (musyawarah guru mata peelajaran) sehingga setiap siswa dapat menjadi sumber daya manusia yang berkualitas, kompetitif dan produktif dapat menjadi aset Nasional dalam menghadapi persaingan dunia yang semakin ketat,

\section{Kesimpulan}

Berdasarkan hasil penelitian dan pembahasan yang telah dilakukan maka dapat ditarik kesimpulan sebagai berikut:

Komunikasi dan motivasi kerja kepemimpinan kepala sekolah berpengaruh secara signifikan terhadap kinerja tenaga pendidik, di MA Matholi'ul Anwar Kab. Lamongan. Agar tercipta lembaga pendidikan yang demokratis, sistematis dan kondusif, yang sesuai dengan harapan lembaga pendidikan

Kepemimpinan yang baik berpengaruh secara parsial terhadap kinerja tenaga pendidik, di MA Matholi'ul Anwar Kab. Lamongan dilihat dari sikap terbukanya kepala sekolah terhadap bawahannya, terhusus tenaga pendidik di tenaga Pendidik, di MA Matholi'ul Anwar Kab. Lamongan.

Dari kesimpulan hasil penelitian dapat diambil saran untuk MA Matholi'ul Anwar Kab. Lamongan sebagai berikut:

Dari hasil analisis kepemimpinan di MA Matholi'ul Anwar Kab. Lamongan, Komunikasi dan motivasi kerja yang berpengaruh signifikan ialah kepemimpinan maka pihak atasan atau pemimpin lembaga pe \ndidikan mempertahankan kepemimpinannya kepada bawahannya agar kinerja tenaga pendidik dapat bekerja dengan baik dan maksimal.

Selain itu, berikan edukasi kepada tenaga pendidik mengenai pentingnya profesionalitas tenaga pendidik agar kegiatan belajar mengajar terlaksana dengan baik dan mengurangi kejadian kekosongan kelas. 
Saran bagi peneliti selanjutnya, peneliti harapkan dapat melanjutkan penelitian tentang kepemimpinan, komunikasi dan motivasi kerja terhadap kinerja tenaga pendidik dengan menggunakan variabel tambahan yang dapat memperkuat asumsi penelitian.

References 